DUNAMIS (Jurnal Teologi dan Pendidikan Kristiani)

Volume 2, Nomor 1 (Oktober 2017)

ISSN 2541-3937 (print), 2541-3945 (online)

http://www.sttintheos.ac.id/e-journal/index.php/dunamis

Submitted: 05 September 2017

Accepted: 31 Oktober 2017

Published: 31 Oktober 2017

\title{
Analisis 1 Korintus 14:2-6 Tentang Karunia Berbahasa Roh dan Bernubuat
}

\author{
Desti Samarenna \\ Sekolah Tinggi Teologi Internasional Harvest Semarang \\ destisamarenna@gmail.com
}

\begin{abstract}
The spiritual gifts about speaking in tongue and prophecy are theological issues which getting its dynamics in both Pentecostal and Charismatic. There some frictions resulted disunity churches. This is a research which had purpose to show a distinguished function and benefit of those two gifts in church service. This research used a method of text analysis on 1 Corinthians 14:2-6 which about those two spiritual gifts, speaking in tongue and prophecy. The results of analysis are: Speaking in tongue is a gift of communicating to God with benefit of self developing, and prophecy is a gift given for stating something from God to people.
\end{abstract}

Keyword: spiritual gifts; speaking in tongue; prophecy

\begin{abstract}
Abstrak
Karunia bahasa roh dan nubuat merupakan isu teologis yang terus mengalami dinamika dalam tubuh Pentakosta maupun Kharismatik. Tidak sedikit terjadi friksi yang mengakibatkan perpecahan. Tujuan penelitian ini adalah menunjukkan perbedaan antara kedua karunia tersebut, termasuk manfaat dan fungsinya dalam ibadah. Artikel ini merupakan penelitian yang menerapkan metode analisis teks, khususnya 1 Korintus 14:2-6 yang membahas tentang penggunaan dua karunia tersebut. Hasil dari pembahasan didapatkan bahwa karunia berbahasa roh merupakan bahasa komunikasi yang dibangun kepada Allah dan berfungsi untuk membangun dirinya sendiri, sementara nubuat merupakan karunia yang diberikan Allah untuk menyatakan sesuatu dari Allah kepada manusia.
\end{abstract}

Kata Kunci: bahasa roh; karunia roh; nubuat 


\section{PENDAHULUAN}

Karunia adalah hal yang sering menjadi perbincangan secara umum, khususnya tentang karunia roh. Tidak jarang muncul friksi yang mengakibatkan perpecahan di dalam gereja, hanya oleh perspektif yang berbeda. Hal inilah yang mendorong penulis melakukan riset biblikal (literatur) untuk menjelaskan karunia roh tersebut berdasarkan konteks Alkitab dalam 1 Korintus 14:1-6. Karunia adalah anugerah yang wajar untuk setiap orang percaya yang setia meskipun dibagikan secara berbeda satu dengan yang lain (Rom 12:6). Istilah karunia umumnya diterjemahkan dari Bahasa Yunani: "kharisma” ( $\chi \alpha \dot{\rho} \rho\llcorner\sigma \alpha)$ dengan kata dasar kharis ( $\left.\chi \alpha \rho_{\rho} \iota \varsigma\right)$, menekankan hakikat pemberian yang diberikan secara cuma-cuma. ${ }^{1}$

Kota Korintus merupakan pusat perdagangan yang penting dan kota ini terkenal dengan segala kerusakan akhlak dan kebejatan moral karena memiliki Kuil Afrodit. Oleh karena itu Paulus mengunjungi Korintus memberitakan Injil. Sesudah kunjungan itu, paulus menulis surat kepada jemaat yang ada disana karena mendengar berita-berita yang tidak menyenangkan. Kemudian Paulus menyelesaikan maslah tersebut dengan berkunjung kembali dan memberikan teguran keras kepada jemaat. Pasal yang penting membahas tenrtang kebangkitan dan karunia-karunia rohani dalam 1 Korintus 12; 13; 14. Kitab Korintus

\footnotetext{
${ }^{1}$ W. R. F. Browning, Kamus Alkitab (Jakarta: BPK Gunung Mulia, 2007), 173.
}

adalah surat Paulus yang paling panjang. ${ }^{2}$

Paulus memberikan argumentasi bahwa jika orang Kristen sekarang menghargai arti kasih yang paling tinggi itu, mereka diharapkan mencari apa yang terbaik yang diharapkan Allah. Kondisi jemaat Korintus mengakui kehendak Roh yang berdaulat dalam membagi-bagikan karuniaNya, maka mereka harus memperoleh karunia-karunia tersebut (1 Kor. 12:1).

Roh Kudus dapat memanifestasikan diri-Nya dalam bentuk karunia-karunia roh. Setiap orang yang menerima Roh Allah dapat bernubuat (1 Kor. 14:31; Kis. 2:1718). ${ }^{3}$ Tanpa penyataan dari Allah, nubuat tidak ada. Dalam konteks Korintus, penyataan adalah nubuat, di mana nubuat dalam hal ini bukanlah suatu wahyu baru, melainkan suatu penjelasan tentang firman Tuhan atau tafsiran bahasa roh dalam bahasa yang lebih mudah dimengerti dan bermanfaat bagi semua orang. Nubuat juga adalah petunjuk dari Tuhan, dimana kebenaran yang disampaiakan di depan jemaat, dengan tujuan manusia dapat mengenal Tuhan dan dilakukan secara teratur. Penyataan didapatkan ketika sedang duduk atau dalam keadaan tenang, bukan

\footnotetext{
${ }^{2}$ S. Lewis Johnson, "1 Korintus," in Wycliffe Bible Commentary (Perjanjian Baru), Vol.3. (Malang: Gandum Mas, 2001).

${ }^{3}$ David L. Baker, Roh Dan Kerohanian Dalam Jemaat: Tafsiran Surat 1 Korintus 12-14 (Jakarta: BPK Gunung Mulia, 1991), 158.
} 
secara spontan, dan tidak semua orang yang mendapatkannya. Untuk memahami karunia roh maka ada beberapa hal yang diperhatikan dalam analisis 1 Korintus 14:2-6.

\section{METODOLOGI}

Penelitian ini menggunakan metode dengan pendekatan kualitatif yang berfokus pada studi pustaka. Metode pembahasan adalah analisis teks pada Alkitab, yakni tentang karunia roh dalam 1 Korintus 14:2-6. Penelitian ini menerpakan prinsip-prinsip yang berkaitan dengan hermeneutika Alkitab sehingga menghasilkan paparan yang kontekstual dan biblikal. Penggunaan beberapa teori sebagai referensi digunakan untuk memahami konsep karunia Roh Kudus dalam penggunaannya secara luas.

\section{ANALISIS DAN HASIL PEMBAHASAN}

Analisis teks pada kitab 1 Korintus 14:2-6 akan dijelaskan secara ayat per ayat. Pembahasan akan menggunakan nats asli dalam Bahasa Yunani.

\section{Ayat 2}

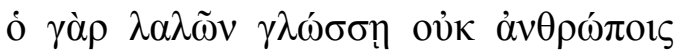

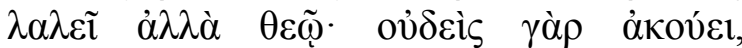
$\pi v \varepsilon v ́ \mu \alpha \tau \imath \delta \dot{\varepsilon} \lambda \alpha \lambda \varepsilon \tilde{\imath} \mu v \sigma \tau \eta \dot{\rho} \rho \iota$.

(Siapa yang berkata-kata dengan bahasa roh, tidak berkata-kata kepada manusia, tetapi kepada Allah. Sebab tidak ada seorang pun yang mengerti bahasanya; oleh Roh ia mengucapkan hal-hal yang rahasia).

Dalam teks pada pasal 2 ini, dimulai dengan konjungsi $\gamma \grave{\alpha} \rho$ (karena) berfungsi menyatakan dasar bagi pernyataan yang mengikutinya. Paulus menjelaskan kepada siapa karunia itu ditujukan dengan menjelaskan subyek berbentuk partisif, dengan artikel ó dan $\lambda \omega ́ \sigma \sigma \eta ̣$ yang berbentuk datif berfungsi menjelaskan sarana yang digunakan untuk melaksanakan tindakan. Orang yang berkata-kata dengan bahasa roh dalam hal ini bahasa lidah ditujukan kepada Allah sebagai objeknya.

Kata kerja berkala kini $\lambda \alpha \lambda \in \hat{\imath}$ dengan

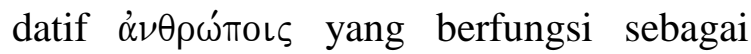
objek tidak langsung, beserta kata keterangan negatif oט̉к, dan diterjemahkan dengan bukan kepada manusia. Konjungsi $\dot{\alpha} \lambda \lambda \grave{\alpha}$ sebagai penghubung kontras dengan datif $\Theta \epsilon \hat{\omega}$ yang juga berfungsi sebagai objek tidak langsung, dan diterjemahkan dengan melainkan kepada Allah. Adanya anak kalimat dengan konjungsi yò

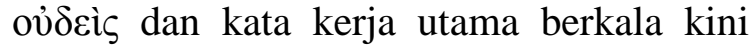

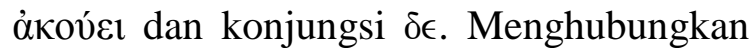
kalimat dari anak kalimat, dengan kata kerja utama berkala kini $\lambda \alpha \lambda \in \hat{\imath}$ dan datif $\pi v \varepsilon v ́ \mu \alpha \tau \imath$ yang menjelaskan kata kerja dan berfungsi sebagai pelaku dari kata kerja, dan diterjemahkan dengan "oleh Roh."

Jika memperhatikan teks ini lebih dalam, ada penjelasan yang menarik bahwa 
orang yang berkata-kata dengan bahasa lidah, berkata-kata kepada Allah. RohNyalah yang menjadi sumber perkataan tersebut, dan ditujukan kepada Allah dan bukan kepada manusia, karena manusia tidak mengerti sama sekali. Memperhatikan "kata tidak mengerti" bukan tidak ada artinya, jika ada yang bisa menafsirkannya karena akhirnya bisa dimengerti orang lain. Bagian ini menjelaskan fungsi bahasa roh yang utama adalah untuk berbicara kepada Allah, bukan kepada manusia. ${ }^{4}$

Pengertian berbicara kepada Allah dalam konteks menggunakan bahasa roh tidak dapat digeneralisir dengan pemahaman berdoa kepada Allah seperti pada umumnya dilakukan. Karena jika demikian, maka Allah tidak terbatas dengan bahasa apa pun sehingga tidak harus menggunakan bahasa khusus untuk Allah dapat mengerti ungkapan manusia dalam doa. Berdoa dengan berbahasa roh terjadi oleh karena dorongan Roh Kudus dengan maksud dan tujuannya sendiri. ${ }^{5}$ Ini persoalan pada maksud Roh itu sendiri yang memiliki tujuan memberikan karunia tersebut dalam konteks ibadah atau doa,

\footnotetext{
${ }^{4}$ Hermanto Suanglangi, "Bahasa Roh: Apa Dan Bagaimana?," Jurnal Jaffray Vol. 2, no. 1 (April 1, 2005): 17-25, accessed July 27, 2017 , http://ojs.sttjaffray.ac.id/index.php/JJV71/article/vie w/146.

${ }^{5}$ Evan Siahaan, "REFLEKSI ALKITABIAH FENOMENA GLOSSOLALIA," Jurnal Antusias Vol. 2, no. 1 (January 2012): 160-179, accessed October 29, 2017, http://www.sttintheos.ac.id/ejournal/index.php/antusias/article/view/67/66.
}

sehingga tidak dapat digeneralisir pada persoalan yang lebih luas. Artinya, relasi itu harus dipahami dalam konteks relasi yang lebih dari pada umumnya, melibatkan dimensi praksis.

\section{Ayat 3}

ó $\delta \grave{\varepsilon} \quad \pi \rho \circ \varphi \eta \tau \varepsilon v ́ \omega v \quad \alpha \dot{\alpha} \theta \rho \omega ́ \pi 01 \varsigma \quad \lambda \alpha \lambda \varepsilon \tilde{\imath}$

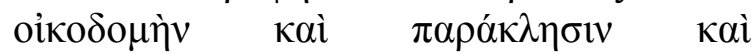
$\pi \alpha \rho \alpha \mu v \theta i \alpha \alpha$.

(Tetapi siapa yang bernubuat, ia berkatakata kepada manusia, ia membangun, menasihati dan menghibur).

Dalam ayat 3 dengan konjungsi $\delta ’ \epsilon$ (tetapi) memiliki fungsi yang kontras dengan ayat kedua. Kata $\pi \rho \varphi \eta \tau \varepsilon v ́ \omega v$ berfungsi substantifal dengan artikel ó, dan diterjemahkan sebagai subjek, "orang yang bernubuat." Kata kerja utama juga sama dengan ayat $2, \lambda \alpha \lambda \varepsilon \tilde{\imath}$ dan $\alpha \dot{v} \theta \rho \omega ́ \pi 01 \varsigma$ datif yang berfungsi sebagai objek tidak langsung, diterjemahkan dengan "kepada manusia." Ada objek yang menjadi tujuan dari bernubuat yaitu kepada manusia. Dengan bernubuat ada tiga tujuan yang dicapai, dalam bentuk akusatif, yakni:


(menasihati), dan $\pi \alpha \rho \alpha \mu v \theta i ́ \alpha v$ (menghibur) yang berfungsi sebagai objek langsung dan masing-masing dihubungkan dengan konjungsi $\kappa \alpha i$.

Oleh karena objek atau penyampaian karunia nubuat adalah $\dot{\alpha} v \theta \rho \omega ́ \pi$ ors (manusia) dalam bentuk datif yang berfungsi sebagai 


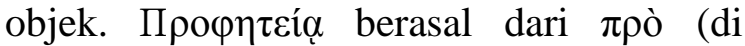
hadapan) dan kata $\varphi \eta \mu$ (mengatakan); keseluruhan berarti "mengatakan di hadapan." Ini bukan berbicara di hadapan berkaitan dengan waktu, tapi berkaitan dengan objek/audiens; jadi "mengatakan di hadapan orang" atau "berbicara kepada orang lain" atau "berbicara di depan umum."

Baik karunia nubuat maupun bahasa roh, berada di bawah pengaruh Roh Kudus. Keduanya berbicara tentang hal yang benar. ${ }^{6}$ Namun satu berbicara dalam bahasa yang jelas, sesuai dengan bahasa pendengarnya; sedangkan yang satu lagi berbicara dalam bahasa yang tidak dikenal. Obyek nubuat kepada manusia ini yang menjelaskan tujuan yang diinginkan Allah. Kalau memperhatikan ciri-ciri dari bahasa Roh yang dikemukakan Paulus, sebelum dibedakan dengan karunia nubuat. Sifat atau tujuan dari bahasa roh tidak bisa membangun jemaat (ay 4). Tidak bisa membangun jemaat, hanya bisa membangun diri sendiri, berarti tidak ada kasih di dalam diri orang yang melakukannya. Pribadi orang yang melakukannya tidak akan dihargai (ay. 5) dikarenakan tidak ada kasih tadi. Cara penyampaian bahasa dalam kata-kata yang tidak jelas (ay. 9). Paulus melukiskannya dengan alat musik seruling dan kecapi

${ }^{6}$ Ibid.
(LAI). Baik seruling dan kecapi ada artinya jika menghasilkan variasi bunyi yang penuh dengan arti. Membunyikan dengan tujuan yang tidak jelas, tidak ada atinya sama sekali.

Nubuat adalah karunia yang diberikan kepada dan di dalam gereja, yaitu bentuk khusus yang Roh berikan dan kerjakan dalam gereja. ${ }^{7}$ Kelebihan karunia nubuat mempunyai tujuan yang tidak berpusat pada diri sendiri, melainkan untuk menyampaikan sesuatu dalam rangka membangun jemaat. Kata membangun

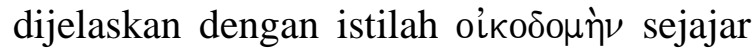
dengan bentuk lainnya seperti $\pi \alpha \rho \alpha ́ \kappa \lambda \eta \sigma \iota \nu$ (menasihati) dan $\pi \alpha \rho \alpha \mu \nu \theta i \alpha \alpha \nu$ (menghibur) dipergunakan Paulus dalam bagian ini. Secara literal оiкобонฑ̀ berarti “membangun sebuah rumah" (Mat. 7:24). ${ }^{8}$ Sedangkan dalam konteks karunia roh, berarti "bangunan" sebagai suatu proses "pembangunan" atau membuat bangunan", atau juga "keadaan membangun"; dan makna figuratifnya menguatkan iman/ kerohanian, atau pembangunan rohani. "Membangun" berarti bertujuan menghasilkan karakter tertentu.

Kata $\pi \alpha \rho \alpha ́ \kappa \lambda \eta \sigma ı v$ yang berasal dari $\pi \alpha \rho \alpha ́ \kappa \lambda \eta \sigma i \varsigma$ punya arti yang luas. Akar kata ini memberikan arti "meminta",

\footnotetext{
${ }^{7}$ Herman Ridderbos, Paulus: Pemikiran Utama Theologinya (Surabaya: Momentum, 2008), 478.

8“Bible Works 7," 2007.
} 
"menasehati", "memanggil." Kata ini juga bisa berarti "meminta dengan sangat untuk ditolong/dihibur”, “penghiburan atau nasehat", bisa juga "bujukan", “dorongan", “desakan.” Arti $\pi \alpha \rho \alpha ́ \kappa \lambda \eta \sigma ı \varsigma$ dalam ayat 3 perluasan dari “teguran", contohnya teguran supaya hidup berkenaan dengan Injil (Rom 12:1; Ibr 13:22) untuk "menghibur" mereka seperti yang dijelaskan dalam 1 Tesalonika 3:2-3 "menghibur" mereka selama dalam penderitaan. Jadi arti ini bukanlah teguran belaka, tapi teguran yang sifatnya menghibur supaya bertindak benar. Dalam $\pi \alpha \rho \alpha ́ \kappa \lambda \eta \sigma ı \varsigma$, penghiburan membutuhkan argumen; nasehat, atau penghiburan, atau dorongan semangat kepada seseorang yang dilihat dari kata-kata yang disampaikannya.

Paulus juga menggunakan kata $\pi \alpha \rho \alpha \mu v \theta i \alpha \nu$ berdampingan dengan $\pi \alpha \rho \alpha ́ \kappa \lambda \eta \sigma v$, untuk menjelaskan maksud atau tujuan nubuat. Kata ini juga berarti "nasehat/dorongan", khususnya "penghiburan"; agak sulit membedakannya dari $\pi \alpha \rho \alpha ́ \kappa \lambda \eta \sigma ı$ Dalam kata ini mengandung penjelasan dan solusi atas hal

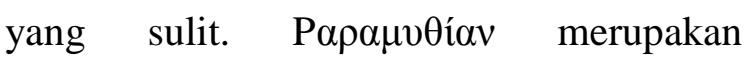
dorongan berupa rasa simpati. Contohnya sama-sama menangis dengan keadaan mereka yang perlu dihibur. Contoh lain yang terdapat dalam 1 Tesalonika 5 ayat 14,

\footnotetext{
${ }^{9}$ Henry George Liddell and Robert Scott, GreekEnglish Lexicon (New York: Oxford University Press, 1985), 1313.
}

kata ini lebih kepada membela mereka yang lemah; mendorong mereka yang lemah pikiran yang ditunjukkan lebih kepada kebaikan daripada kata-kata penghiburan. Ini bisa menjadi acuan membedakan

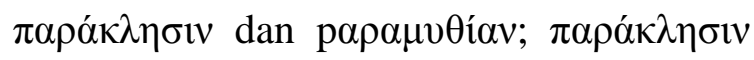
lebih kepada perkataan penghiburan,

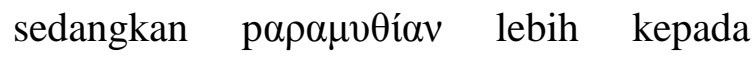
tindakan/menunjukkan kebaikan.

\section{Ayat 4}

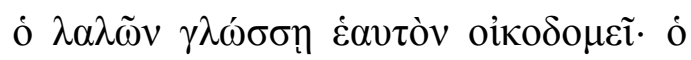

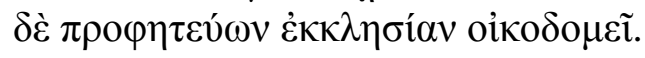

(Siapa yang berkata-kata dengan bahasa roh, ia membangun dirinya sendiri, tetapi siapa yang bernubuat, ia membangun Jemaat).

Ayat 4 kalau diperhatikan dalam teks ini, sama seperti dengan ayat 2 dan 3 . Ada 2 kalimat. Yang pertama, partisif $\lambda \alpha \lambda \tilde{\omega} v$ berfungsi substantifal yaitu sebagai subjek


dengan objek langsung berbentuk pronoun


juga berfungsi substantifal, dengan kata

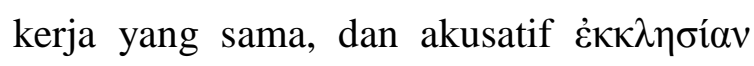
berfungsi sebagai objek langsung.

Dalam Yunani klasik ini bisa menunjukkan suatu keadaan yang dibuat untuk maksud membujuk/mengajak/ meyakinkan, atau untuk membangkitkan, menenangkan, ataupun menghibur. 10

\footnotetext{
${ }^{10}$ Joseph Henry Thayer, Greek-English Lexicon of the New Testament (Grand Rapids: Zondervan, 1889), 485.
} 
Nasehat untuk taat dan melayani sama halnya dengan dorongan dan penghiburan dari Roh Kudus kepada mereka yang mengalami sakit dan masalah, merupakan aspek dimana Roh Kudus membangun jemaat melalui nubuatan.

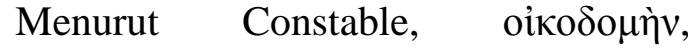
$\pi \alpha \rho \alpha ́ \kappa \lambda \eta \sigma \mathfrak{~}$, dan $\pi \alpha \rho \alpha \mu v \theta i ́ \alpha v$, menyatakan cara-cara utama dalam bernubuat. Dalam hal ini dia menyamakannya dengan berkhotbah, yang tujuannya membangun gereja/jemaat. Tujuan utamanya sebagai sebuah karunia bukan untuk memberikan prediksi tentang kejadian di masa yang akan datang, melainkan untuk membangun orang-orang percaya di masa kini. Hal ini dapat dipahami bahwa nubuat sama dengan khotbah modern, yang bersifat mengajar atau membangun umat Tuhan. ${ }^{11}$ Namun demikian, sekalipun hal tersebut mempunyai tujuan yang mirip, namun tetap ada perbedaan, di mana nubuat merupakan akibat langsung dari ilham Allah, sedangkan khotbah yang adalah nubuat uraian berdasarkan firman Allah yang dicetuskan oleh manusia. Khotbah sering mengandung perkataan, "mari kita mendengarkan Firman Tuhan,' tetapi biasanya maksudnya bahwa Firman Tuhan

\footnotetext{
${ }^{11}$ Kevin Tonny Rey, "KHOTBAH

PENGAJARAN VERSUS KOTBAH

KONTEMPORER," DUNAMIS ( Jurnal Teologi dan Pendidikan Kristiani ) Vol.1, no. 1 (2016): 3151, www.sttintheos.ac.id/ejournal/index.php/dunamis.
}

dikutip dari Alkitab kemudian dijelaskan, dan penjelasan itu sendiri tidak dinyatakan sebagai firman Tuhan. Perhatikan juga bahwa "nasihat" didaftarkan sebagai karunia tersendiri dalam Roma. 12:8, jadi tidak hanya dilaksanakan oleh orang-orang yang menerima karunia nubuat. Boleh dikatakan bahwa pemberian nasihat juga merupakan salah satu tugas yang penting untuk gembala (Ef. 4:11), sehingga karunia nubuat tidak dapat disamakan begitu saja dengan khotbah.

Tujuan ini diulang dan ditekankan kembali oleh Paulus di ayat-ayat selanjutnya (ay 12, 17, 26). Konteks ini dijadikan Paulus untuk menegur praktek bahasa roh yang berlebihan dari tengahtengah jemaat Korintus, dengan menekankan tujuan-tujuan di atas, sebagai langkah membuka kesadaran mereka akan hal yang lebih diinginkan Allah daripada menurut kesenangan mereka.

\section{Ayat 5}

$\theta \dot{\lambda} \lambda \omega \quad \delta \dot{\varepsilon} \quad \pi \alpha \dot{\alpha} v \tau \alpha \varsigma \quad \grave{v} \mu \tilde{\alpha} \varsigma \quad \lambda \alpha \lambda \varepsilon \tilde{\mathrm{I} \nu}$

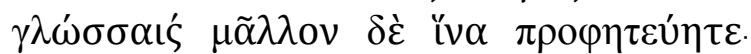



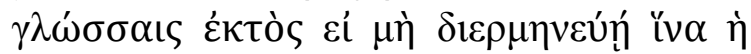

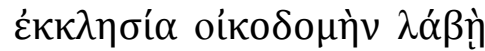

(Aku suka, supaya kamu semua berkatakata dengan bahasa roh, tetapi lebih dari pada itu, supaya kamu bernubuat. Sebab orang yang bernubuat lebih berharga dari pada orang yang berkata-kata dengan bahasa roh, kecuali kalau orang itu juga menafsirkannya, sehingga Jemaat dapat dibangun) 
Ayat 5 dengan kata kerja utama berkala kini $\theta \varepsilon ́ \lambda \omega$ diikuti dengan bentuk infinitif $\lambda \alpha \lambda \varepsilon \tilde{i} v$ yang berfungsi untuk menyatakan kutipan tidak langsung. Jika verbanya bergagasan "mengharap, menjanjikan, memerintahkan" atau sejenisnya, maka infinitif atau klausa infinitif itu memiliki kesamaaan peran dengan kutipan tidak langsung. Disini infinif berfungsi sebagai kata kerja pokok dalam kutipan tidak langsung. Subjeknya adalah kata benda akusatif. Subjek untuk kutipan tidak langsung adalah kata benda akusatif $\dot{v} \mu \tilde{\alpha} \varsigma$. Konjungsi iv $\alpha+$ modus subjungtif ( tujuan dari kata kerja $\theta \varepsilon ́ \lambda \omega$, diterjemahkan dengan “supaya kalian bernubuat.” Kalimat selanjutnya dengan konjungsi de. yang berfungsi sebagai makna penjelasan, dimana partisif $\pi \rho \circ \varphi \eta \tau \varepsilon v \omega v$ bertindak sebagai subjek. Untuk menyatakan keberadaan subjek ó $\pi \rho \circ \varphi \eta \tau \varepsilon v ́ \omega v$, kata kerja evstin. Adjektif $\mu \varepsilon i \zeta \omega \nu$ berfungsi untuk menyatakan perbandingan dengan kata benda lainnya (ò $\lambda \alpha \lambda \tilde{\omega} v \gamma \lambda \omega ́ \sigma \sigma \alpha 1 \zeta)$.

Fungsi perbandingan diperjelas dengan konjungsi î. Diterjemakan dengan "atau",

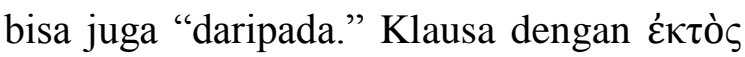

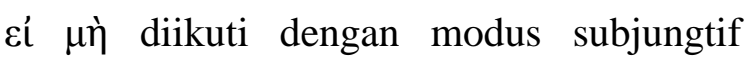

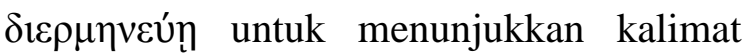
bersyarat (menegaskan relaitas syaratnya). Klausa berikutnya merupakan anak kalimat

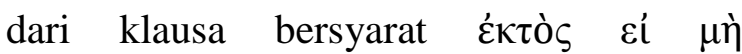




tujuan dari kata kerja, dengan subjek kalimat $\dot{\eta} \dot{\varepsilon} \kappa \kappa \lambda \eta \sigma i ́ \alpha$ dan objek langsung

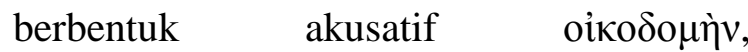
diterjemahkan dengan 'supaya jemaat (menjadi) dibangun/ supaya jemaat dapat dibangun (LAI)."

Karunia nubuat supaya firman Tuhan didengar dan diaplikasikan dalam hidup (22-25, 31-33). Nubuat merupakan firman Allah yang langsung disampaikan kepada jemaat. Baker tidak setuju menyamakan nubuat dengan khotbah. Ia juga mengutip pendapat Grudem, yang juga membedakan nubuat dari pengajaran. Pengajaran merupakan pengulangan, penjelasan dan penerapan nats-nats Alkitab atau tradisi yang diterima dari para rasul (Kis. 18:11, 25; 1 Kor. 15:3; 2 Tes. 2:15); sedangkan nubuat dalam Perjanjian Baru berdasar pada suatu pernyataan khusus (1Kor. 14:6, 2425, 29-30), yang pada konteks ini dibedakan secara langsung penggunaannya dengan karunia berbahasa roh. ${ }^{12}$ Paulus sendiri pernah mempertentangkan pengajaran dengan penyataan (Gal. 1:12). Baker juga mengutip pendapat Grudem, bahwa wibawa firman Tuhan dalam nubuat

\footnotetext{
${ }^{12}$ Robert J. Gladstone, "SIGN LANGUAGE IN THE ASSEMBLY: HOW ARE TONGUES A SIGN TO THE UNBELIEVER IN 1 COR 14:20-25?," Asian Journal of Pentecostal Studies Vol. 2, no. 2 (1999): 177-193, http://www.apts.edu/index.cfm?\&menuid=94.
} 
terdapat dalam isi nubuat itu dan tidak tentu dalam kata-katanya sendiri; ada kemungkinan peran nabi dalam memilih bentuk dan bahasa yang dipakai dalam menyampaikan firman Allah kepada umatNya; tapi James Dunn menegaskan bahwa kata-katanya juga diilhami oleh Roh.

Penyelidikan terhadap teks berikut bertujuan menemukan apakah karunia nubuat seperti ini yang dimaksudkan dalam Korintus dan yang berlaku dewasa ini. Jika nabi tidak punya penguasaan diri atas karunia mereka, ada kemungkinan ketertiban dalam jemaat akan hilang. Paulus melihat karakter Allah sebagai jaminan melawan seperti halnya kekacauan. Allah, akan membuat damai sejahtera, bukan kekacauan, karena Dia bukanlah Allah kekacauan. Conon Leon Morris, dalam bukunya The First Epistle Of Paul To The Corinthians, 196. Menjelaskan penguasaan diri sendiri merupakan salah satu bukti bahwa Roh sungguh bekerja dalam pertemuan jemaat itu. Salah satu pelayanan Roh ialah menertibkan keadaan yang kacau balau (Kej. 1). Kekacauan berasal dari Iblis, bukan dari Allah (Yak. 3:13-18). Apabila roh memimpin, orang-orang yang mengambil bagian dapat melayani "seorang demi seorang" sehingga pengaruh yang menyeluruh tentang pemberitaan dari Allah itu dapat diterima oleh jemaat. David L. Baker, menjelaskan juga bahwa dengan pelayanan nubuat seharusnya tunduk kepada pengawasan kepemimpinan pastoral. ${ }^{13}$ Sering orang yang mempunyai karunia nubuat mau menerima penyataan dengan suatu penjelasan murni dan kuasa roh di mana hasratnya untuk bernubuat mengesampingkan panggilan untuk bersabar.

\section{Ayat 6}





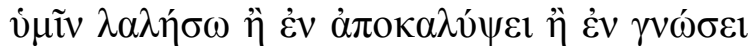

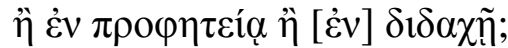

(Jadi, saudara-saudara, jika aku datang kepadamu dan berkata-kata dengan bahasa roh, apakah gunanya itu bagimu, jika aku tidak menyampaikan kepadamu penyataan Allah atau pengetahuan atau nubuat atau pengajaran?)

Di ayat 6 dengan konjungsi $\delta \varepsilon ́$ dan kata keterangan nũv berfungsi menyatakan kontinuasi dari ayat 2-5. Kata kerja utama berkala futur $\dot{\varphi} \varphi \varepsilon \eta \dot{\sigma} \omega$ yang berfungsi secara deliberatif. Sering kali dinyatakan dengan memakai kata kerja indikatif futur, dengan subjek orang pertama tunggal atau jamak. Tujuannya bukan untk mencari fakta atau apa yang bakal terjadi, melainkan berkepentingan dengan masalah tindakan (apa yang harus dilakukan).

Ada dua anak kalimat bersyarat yang mengikuti kata kerja utama; kedua-duanya bermodus subjungtif (๕̌ $\lambda \theta \omega$ dan $\lambda \alpha \lambda \eta ́ \sigma \omega)$

\footnotetext{
${ }^{13}$ Baker, Roh Dan Kerohanian Dalam Jemaat: Tafsiran Surat 1 Korintus 12-14.
} 
yang dinyatakan dengan śà̀ dan ċò̀ $\mu \grave{\eta}$. Partisif pada klausa pertama $(\lambda \alpha \lambda \tilde{\omega} v)$ berfungsi adverbial menjelaskan cara yang dipergunakan untuk melaksanakan kegiatan yang disebutkan kata kerja $\check{\varepsilon} \lambda \theta \omega$, diterjemahkan "dengan berbahasa lidah." Klausa kedua memiliki 5 kata dengan kasus datif, empat di antaranya menggunakan preposisi $\dot{\varepsilon} v$ yang masing-masing dihubungkan dengan kata penghubung ì, yang berfungsi sebagai korelasi konjungsi, yang diterjemahkan dengan "tidak hanya... tetapi juga." Kehidupan rohani adalah kehidupan Kristus yang direproduksi di dalam hidup orang percaya. ${ }^{14}$ Hidup yang dijalankan orang-orang percaya adalah hidup oleh iman dalam Kristus yang telah menyerahkan diri-Nya untuk mereka. Sebelumnya bagi jemaat di Korintus, orang percaya dianggap rohani jika ia punya karunia roh. Dengan karunia roh yang ada, mereka merasa tidak membutuhkan anggota-anggota lain. Mereka meremehkan anggota gereja yang kecil dan lemah, karena dianggap kurang rohani. Dengan melihat sikap yang seperti ini, Paulus berusaha meluruskan ketidakdewasaan rohani yang terjadi di Korintus, dengan harapan mereka bisa mengetahui dengan jelas apa itu karunia rohani dan apa itu

\footnotetext{
${ }^{14}$ Pete Deison, "Dengan Kuasa Roh Kudus," in Berkhotbah Kehidupan Rohani (Yogyakarta: STTII Yogyakarta, 2010), 2.
}

kerohanian. ${ }^{15}$ Mereka harus dewasa secara rohani dan bukan seperti kanak-kanak.

Karunia rohani itu sendiri tidaklah salah; justru kerohanian orang-orang yang memiliki karunia tersebut yang kerap melakukan kesalahan. Hal ini menunjukkan bahwa mereka belum dewasa dalam Kristus (1Kor 3: 1-3). Karunia rohani bukanlah tanda kerohanian atau sebuah status di dalam gereja, namun lebih merupakan sebuah perlengkapan untuk melayani. ${ }^{16}$ Kerohanian dihubungkan dengan karunia rohani, tetapi tidak seperti anggapan jemaat Korintus. Jemaat Korintus pada pasal 12 menganggap karunia-karunia rohani tertentu adalah bukti dari kehebatan rohani mereka. Jika Roh Kudus memberikan karunia roh kepada orang percaya, yang terjadi seharusnya adalah kerohanian mereka harus lebih meningkat kualitasnya. Artinya, kehidupan rohani dengan pengalaman pribadi bersama Roh Kudus harus menjadi indikator kualitas seseorang dalam melayani Tuhan. ${ }^{17}$ Kehidupan rohani

\footnotetext{
${ }^{15}$ Daniel Ronda, "Kepenuhan Roh Kudus," Jurnal Jaffray 4, no. 1 (June 1, 2006): 30, accessed November 1, 2017,

http://ojs.sttjaffray.ac.id/index.php/JJV71/article/vie w/131.

${ }^{16}$ Gladstone, "SIGN LANGUAGE IN THE ASSEMBLY: HOW ARE TONGUES A SIGN TO THE UNBELIEVER IN 1 COR 14:20-25?"

${ }^{17}$ Yushak Soesilo, "PENGALAMAN PRIBADI DENGAN ROH KUDUS SEBAGAI INDIKATOR KUALITAS PELAYANAN," Jurnal Antusias 1, no. 3 (September 1, 2011): 109-117, accessed October 29, 2017, http://www.sttintheos.ac.id/ejournal/index.php/antusias/article/view/79/78.
} 
adalah yang pertama dan yang utama kehidupan Kristus di dalam orang percaya.

\section{KESIMPULAN}

Karunia roh diberikan untuk kepentingan dan kebutuhan pelayanan, baik itu karunia berbahasa roh atau bernubuat. Karunia berbasaha roh digunakan untuk membangun diri sendiri, karena ketika seseorang menggunakannya, maka ia sedang berkata-kata kepada Allah dengan bahasa yang tidak mereka mengerti namun Roh Kudus mendorongnya. Sementara itu nubuat merupakan karunia yang diberikan Allah untuk seseorang menyampaikan sesuatu kepada manusia, karena tujuan nubuat adalah untuk menasihati, menghibur dan menunjukkan kebaikan

\section{DAFTAR PUSTAKA}

Baker, David L. Roh Dan Kerohanian Dalam Jemaat: Tafsiran Surat 1 Korintus 12-14. Jakarta: BPK Gunung Mulia, 1991.

Browning, W. R. F. Kamus Alkitab. Jakarta: BPK Gunung Mulia, 2007.

Deison, Pete. "Dengan Kuasa Roh Kudus." In Berkhotbah Kehidupan Rohani. Yogyakarta: STTII Yogyakarta, 2010.

Gladstone, Robert J. "SIGN LANGUAGE IN THE ASSEMBLY: HOW ARE TONGUES A SIGN TO THE UNBELIEVER IN 1 COR 14:20-25?" Asian Journal of Pentecostal Studies Vol. 2, no. 2 (1999): 177-193. http://www.apts.edu/index.cfm?\&men uid=94.
Johnson, S. Lewis. "1 Korintus." In Wycliffe Bible Commentary (Perjanjian Baru). Vol.3. Malang: Gandum Mas, 2001.

Joseph Henry Thayer. Greek-English Lexicon of the New Testament. Grand Rapids: Zondervan, 1889.

Liddell, Henry George, and Robert Scott. Greek-English Lexicon. New York: Oxford University Press, 1985.

Rey, Kevin Tonny. "KHOTBAH PENGAJARAN VERSUS KOTBAH KONTEMPORER." DUNAMIS ( Jurnal Teologi dan Pendidikan Kristiani ) Vol.1, no. 1 (2016): 31-51. www.sttintheos.ac.id/ejournal/index.php/dunamis.

Ridderbos, Herman. Paulus: Pemikiran Utama Theologinya. Surabaya: Momentum, 2008.

Ronda, Daniel. "Kepenuhan Roh Kudus." Jurnal Jaffray 4, no. 1 (June 1, 2006): 30. Accessed November 1, 2017. http://ojs.sttjaffray.ac.id/index.php/JJV 71/article/view/131.

Siahaan, Evan. "REFLEKSI

ALKITABIAH FENOMENA GLOSSOLALIA.” Jurnal Antusias Vol. 2, no. 1 (January 2012): 160-179. Accessed October 29, 2017. http://www.sttintheos.ac.id/ejournal/index.php/antusias/article/view /67/66.

Soesilo, Yushak. "PENGALAMAN PRIBADI DENGAN ROH KUDUS SEBAGAI INDIKATOR KUALITAS PELAYANAN." Jurnal Antusias 1, no. 3 (September 1, 2011): 109-117. Accessed October 29, 2017. http://www.sttintheos.ac.id/ejournal/index.php/antusias/article/view /79/78.

Suanglangi, Hermanto. "Bahasa Roh: Apa Dan Bagaimana?” Jurnal Jaffray Vol. 2, no. 1 (April 1, 2005): 17-25.

Accessed July 27, 2017. http://ojs.sttjaffray.ac.id/index.php/JJV 71/article/view/146.

“Bible Works 7,” 2007. 